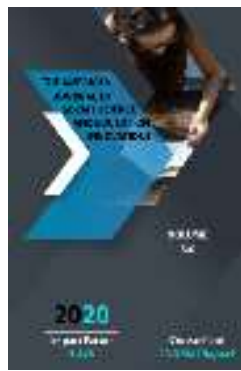

Journal Website: http://usajournalshub.c om/index,php/tajssei

Copyright: Original content from this work may be used under the terms of the creative commons attributes 4.0 licence.

\section{History Of Tashkent In The Researchs Of Russian Scientists (Late XIX - Early - XX Century)}

\author{
Zumrad Rakhmonkulova \\ Head Of The Department "Source Science And Archival Studies" Faculty Of The History \\ Of The National University Of Uzbekistan \\ Burieva Khayriya \\ Acossiated Professor Of The Department "Source Science And Archival Studies" Faculty Of \\ The History Of The National University Of Uzbekistan \\ Sherzodjon Choriev \\ PhD Of The Department "Source Science And Archival Studies" Faculty Of The History Of The \\ National University Of Uzbekistan \\ Yusupova Dildora \\ Assistant Teacher Of The Department "Source Science And Archival Studies" Faculty Of The \\ History Of The National University Of Uzbekistan
}

\title{
ABSTRACT
}

This article analyzes written sources such as books, manuscripts, newspapers and journals of this department of the library belong to different periods of history and allow obtaining an ation for scientific research in many fields. For example, the period of the late XIX - early XX centuries. reflected in the materials of periodicals of local and Russian editions, in documentary sources of control bodies, in individual works of scientists, in the diaries of military and travelers. The scientific works of Russian authors such as A.N. Teternikov, F. Nazarov, P.I. Pashino, L. Kostenko, N. N. Pantusov ON. Maeva, D. I. Evarnitskiy, A. Divaev, A. Shishov, A. I. Dobrosmyslov and A.Shishkin.

\section{KEYWORDS}

Republic of Uzbekistan, Tashkent, Central Asia, Books, manuscripts, newspapers, magazine, Labzak, Takhtapul, Karasaray, Sag'bon, Chig'atay, Kokcha, Samarkand, Kamolon, Behsyag'ach, Koymas, Kokand,Shaykhantahur, Sebzar, Kukcha, Beshyagach

\section{INTRODUCTION}

Over the years of independent development of the Republic of Uzbekistan, specialists have done considerable work to create a real, objective history of Uzbekistan based on reliable sources and historical scientific literature belonging to the periods studied. Most of these sources are kept in the country's archives, libraries and manuscripts. In 
particular, the National Library of the Republic of Uzbekistan, in the department of «Rare Books», there are materials containing a lot of information about the political, socioeconomic, and cultural life of the peoples of Central Asia. Many of these works are primary sources, which undoubtedly increases the value of the works. Books, manuscripts, newspapers and magazines of this department of the library refer to different periods of history and provide information for scientific research in many fields. For example, the end of the 19th and the beginning of the 2oth centuries. is reflected in the materials of the periodical press of local and Russian publications, in documentary sources of government bodies, in individual works of scientists, in diaries of military and travelers.

\section{MAINBODY}

Sources of the 19th century, in particular, in the work of Muhammad Soliq "Tarikhi Jadidayi Toshkan" have information about the history of the city of Tashkent, was also mentioned about the history of the city of the early centuries. He wrote about the 12 gates that were in the city wall surrounding the city. For example, it is written that the names of the 12 gates were named during the period of Amir Temur: Kiyot, Turklar, Kamondaron, Qangli, Beshyag'ach, Qatag'an. For its period this information terrain, the names of aryks(water irrigation) give very valuable information. Information about the history of the city of Tashkent concerning the XIX - of the beginning of the XX centuries is available and Russian sources - diaries of military and travelers, reports of the governor-general, military governor, state assistants and reports of the commission, statistical materials, Publications of the period, various maps, paintings and photographs.

They were written about the geographical location of the city, the terrain, the weather, the gates, the walls, the streets, the stadiums, the waters, and various businesses. In the second half of the 19th century, Gaines wrote about the names of the gate of the city: Labzak, Takhtapul, Karasaray, Sag'bon, Chig'atay, Kokcha, Samarkand, Kamolon, Behsyag' ach, Koymas, Kokand.

A lot of interesting information is found in the works: «Essays of internal trade of the Kyrgyz steppe» V.A.Teternikova [1] , «Notes about some peoples and lands of Central Asia» F.Nazarova [2], «Turkestan region in 1866: Travel notes with 20 lithographs» P.I.Pashino [3], «Information about Russian Tashkent» L.Kostenko[4] , "Materials for industrial and trade statistics» N.N.Pantusov [5], «Asian Tashkent» «Russian Tashkent» N.A.Maev [6], "Guide to Central Asia from Baku to Tashkent. In archaeological and historical relations» D.I.Evarnitsky[7], «Crafts and occupations of native people of the Asian city of Tashkent» A.Divaev [8], «Sarts» A.Shishov [9], «Tashkent in the past and the present» A.I.Dobrosmislov [10], «About the names of the Tashkent makhallas» V.A.Shishkin [11], «Tashkent makhallas and blocks» N.G.Mallicky [12].

This paragraph analyses several works by Russian authors containing important data on the political, socio-economic and cultural life of the city of Tashkent. Most of the articles concerning the history of the province are published in the Turkestan Collection. For example, N.A.Maev's works contain rich material on the history of two parts of the city, which at the time were administrative divisions. In particular, the article "Asian Tashkent" [13] quotes some information in the Old city part of Tashkent at the end of the 19th century. In the first, third, fourth chapters of this work, numbering five chapters, mention is made of four dakha (districts), urban makhallas, rivers, mosques, as well as detailed descriptions of several of these objects. It lists 12 city gates: Koymas, Kokand, Kashgar, Labzak, Takhtapul, Karasaray, Sag'ban, Kucha Mazar, Kukcha, Samarkand, Kamalan, Behsyag'ach.

The author quoted a comment that «daha» among the local population is called "yurt», the 
author himself called them «parts» of the Old city and named them: Shaykhantahur, Sebzar, Kukcha, Beshyagach. Information on the number of makhallas in each of these urban areas and their lists is particularly valuable. In particular, N.A.Maev indicated that 48 makhallas were housed in the Shaykhantahur unit, 38 in Sebzar, 31 in Kukcha and 32 in Beshyagach. The following are statistics on mosques, madrasas and schools. For example, in Shaykhantahur there were 60 mosques, 10 schools, 3 madrasas (such as Ishan-KulliLashkar-kushbegi, Takht-tak, Dikser); in Sebzar there were 10 mosques (Khatyn-mosque, Ohun-guzar, Odin-mosque, Mazar-khan, Muyimburak, Honoki, Tokhtukus, Rabat, KhojiToroson, Kara-sarai), 3 madrasas (Beklar bey, Barokhon, Kizyl-Kurgan); 51 mosques, 34 schools, 2 madrasas in Kukcha part; 68 mosques, 16 schools, 3 madrasas in Beshyagach part. Along with administrative divisions, makhallas and spiritual-educational objects, the author mentions natural objects, more precisely the large rivers flowing in the vicinity of Tashkent (Chirchik, Bossuv, Pskom, Zakharyk, Salar) and its four parts. In particular, in Daha Shaykhantahur: Ankhor, Gadragan; in Daha Sebzar: Kaikauz and the resulting shallow aryks; in Daha Kukcha: Zakharyk, Karakamish, Jangoh (one of the arms of Kaikauz); in Beshyagach: Jatyhirman, Katta Tanishahar, Arpapoya aryk, Kuvaryk, Alamdar.

The reader is attracted by its detailed description of the central market of the Old Town, where the author gave information about the number of trading rows and shops, listed the types of goods sold by merchants, described the activities of craft workshops in this bazaar. It should be noted here that the author gave a very detailed description of the bazaar and did not hide his emotions with some peculiarities of local merchants: "Here is a large bazaar, with its diverse crowd ... where there are shops with all kinds of productivity, grouped by streets and rows (there are 2763 shops in this bazaar) ... Often you will see a completely open shop, the owner of which sits somewhere at another sart, leaving his shop open ... and no one will enter it. I can give an interesting example of a simple way to lock my shops and storerooms: one of the Sarts, a merchant, hired in the Russian part of the city a shed to store barley for the winter. Having poured his supply there, he closed the doors and sealed them with a lump of clay, on which he made his sign. He did not put any locks on the door, fully convinced that no one would open the sealed door ... If you are not familiar with the bazaar and do not have a guide, you will never find what you need in it. In vain you will walk around the bazaar and look out, the sarts will never call you to their shop, just as they will not shout out their goods and sitting on the carpet at the threshold, he will also look at you indifferently when you approach him ... " [15].

The next paper of N.A.Maev, devoted to descriptions of Tashkent, is the article "Russian Tashkent", consisting of six chapters. It contains information about the Novgorod part of the city, or rather, about its geographical position, climate, vegetation, population, transport, buildings, shopping areas, religious institutions, military units, a cemetery, as well as the surroundings of this part of the city. This is how the author of the construction of this part of Tashkent described: “... There are no multi-storey buildings in Tashkent at all, and only two-storey ones are found ... The houses are mostly built of adobe bricks (due to the high cost of wood) ... Administrative buildings and houses of richer individuals were built, of course, from fired brick. One of the characteristic features of the local buildings is also the fact that houses made of baked bricks are never plastered. Turkestan iron ore is not brown-red, but brown-yellow. Thus, the unplastered building does not have an unpleasant red color, and the natural color of the Turkestan iron ore completely replaces the color for the building. This is how the buildings were built: the cathedral in the name of the Transfiguration of the Savior, the palace of His Imperial Highness Grand Duke Nikolai 
Konstantinovich - an elegant building that resembles with its light, graceful facade decorated with figurines of deer - a rich hunting castle ..., six buildings of the Male and Female gymnasiums, the building of the Tashkent branch The State Bank, the Military Assembly and many private houses. Raw brick houses are always plastered and painted, mostly white. It somehow harmonizes with the white color of the Tashkent population, which predominates in summer" [16].

Among the works containing reliable and detailed information about the history of the city of Tashkent at the end of the XIX century. it should be noted the work of A. Shishov "Sarti", in the fourth and fifth parts of which are given information about dakh (districts), makhalla of the Old City, statistical data on districts concerning mosques, madrasahs, schools are given [17]. For example: in the Sheikhantaur part: Lyashkar Beklarbegi, Kasymbay, Khazrat Yunuskhan, Degrez madrasahs; in the Sibzar part: madrasahs Beklarbegi, Barakkhan, mosques - Okhunguzar, Khatunmaschet, Mazarkhan, Muyimuborak, Khonaka, Takhtapul, Rabat, Khoja Tarashkan, Karasaray; in the Kukcha part: Sheikh Zainiddin Baba Madrasah; in the Beshyagach part, the names of three large streets are indicated Samarkand, Kamalyan, Beshyagach; mosque Hazrat Imam Kukeldash madrasah. The data on the large rivers that irrigated the city are given: "Both Asian and Russian Tashkent are irrigated with irrigation ditches drawn from the Chirchik river, which flows 8 versts south of the city. From Chirchik stretches a large irrigation ditch that looks like a river - Zakh-aryk - which runs 10 versts north of the city. The other most important ditch for the city, Bossu, was taken out of Chirchik, 31 miles from the city; at the Lyabzak Gate, it enters Tashkent with two branches and flows through it under various names. " Describing the works of N. Maev and A. Shishov, it is necessary to point out the obvious similarity of many toponyms, statistical data, topographic indicators, which once again confirms the reality of the information and the careful selection of materials by the authors for writing their works.

A special place among the works devoted to the history of Tashkent is occupied by the work of A.I. Dobrosmyslov "Tashkent in the past and the present", created in the nature of a guidebook, consisting of fifteen chapters and containing significant material on the development of urban life in the capital in the late XIX - early XX centuries The author cited data on the changes that took place in Tashkent over the past fifty years, during the performance by the city of the functions of the main city of the Turkestan General Government. The book contains descriptions of the geographical position of the city, its general appearance, its brief history is given, facts about the construction of the New City, its administration, economy, educational, medical, spiritual and cultural institutions and some historical events are given. Referring to the lack of materials about the Old City, the author highlighted in more detail the historical development of the New part of Tashkent. In this regard, he listed water bodies, gardens and parks, shopping facilities, various institutions. In particular, data on 11 large rivers and 77 ditches of medium length are given. The following rivers are mentioned among the "main" ones: Bozsu, Kara-su, Angor, Salar, Kaikuz, Yalangach, Gadragan, Ivish, Kangrak, Darvozakent, Yuz, Bayt-aryk-Kurgan, Uimaut. The author noted that out of 77 "secondary" rivers, the ditches are even smaller, and their number is equal to 83 . Trying to point out the peculiarities of the development of the urban economy over the past fifty years, A.I. Dobrosmyslov drew significant statistics in this area. Thus, he stressed that in 1910 there were more than 1700 industrial and commercial facilities in the city; the author has collected and presented information on the number of these objects according to the branches of the national economy [18]. The work lists large commercial and industrial facilities in this part of the city, such as: Resurrection Bazaar, 
Urdinsky Bazaar, Tashkent Fair, Skotoprigonnaya Square, Wholesale Warehouses; Distillery of Pervushin and his sons, Brewery N.I. Ivanov, Brewery E.Kh. Zhemchuzhnikov, Textile factory Zhemchuzhnikov, Tobacco factory of the partnership of Ivanov's heirs, Tobacco factory of the heirs of Mizgirev and Popov, Cast iron foundry A.E. Gromov, Pugasin's Match Factory, Pasta Factory, Khludov's Tannery, Tezikov's Tannery, Mirbadalov's Oil Mill, Smirnov's Soap Factory, S. I. Lakhtin's Cotton Factory, Vadyaevs' Cotton Factory, I. Khakimbaev's Cotton Factory, D. Ryadov's Cotton Factory, Maslobez , R. Schubert's Rice Cleaning Plant, Pervushin Artificial Ice Plant, Greenberg Mineral Water Plant, Petrov Artificial Water Plant, etc. An important feature of A.I. Dobrosmyslov's information is that he not only lists the names of factories and factories, but also names their founders, location, date of establishment, duration of activity of enterprises and characteristics of the manufactured goods, which are are essential in the study of the economic development of the city.For example, from the information presented in the book by A.I. Dobrosmyslova, "Tashkent in the past and in the present", as well as from the translation of the manuscript of Muhammad Solih "Tarihi zhadidayi Toshkent" you can get interesting materials about the rivers of Tashkent.

The study of the historical aspects of the formation of water bodies is relevant in the light of the coverage of the history of the region, since the development of civilization in Central Asia is closely related to the existence of rivers and canals. They also play a significant role in the history of the city of Tashkent, where for centuries the waters of the rivers were a source of drinking water for the population, were used both for agricultural purposes and for meeting household needs. Archival research revealing the geographic, linguistic, and historical features of hydronyms is valuable information in the study of the emergence and further existence of rivers.
From ancient times to the present day, the territory of Tashkent has been irrigated by rivers flowing from the Bozsu canal. As you know, the relief of the city is characterized by several slopes from the north-east side to the south-west, which caused the numerous branches of large rivers and canals into smaller ones. The number of river canals also grew with population growth and urban expansion. At the present stage, there are 37 rivers and canals of the first category (large and mediumsized), and about a hundred small ones in length. Among them are such as Bozsu, Ankhor, Salar, Kaykovus, Gadragan, Darkhan, Yalangach, Karasu, Akkurgan, Jararyk, Kukcha, Burjar, Pulamas, Rakat, Chupanata, Turtarik, Kuylyuk, Karakamysh, Novza, Labzak, Chilanzar and $\mathrm{dr}$.

The Bozsu Canal is the right branch of the Chirchik River, $158 \mathrm{~km}$ long. It takes its waters in two places - from the Bozsu-Zakh branch and near the Bozsubashi makhalla of the city of Chirchik. It enters the territory of Tashkent from the north, and here, in the city, 25 city rivers originate from it, and flows out in the south, passes through the Chinaz and pours water into the Syrdarya (3).

The hydronym "Bozsu" consists of two components - "boz" ("boz") and "su" ("suv"). The Türkish word "Boz" has several meanings. In particular, it means a color: light gray, sometimes light yellow (for example, the soil of desert lands); this word is widely used by the peoples of the mountainous regions of Central Asia. Some researchers believe that the Bose River is so named because of the grayish color of its waters (4). Also, the word "boz" refers to the type of fabric of hand-made textiles, and in this regard, it is known about the occurrence of several localities with this component. There is also a third meaning of the word "boz", such as "new". And it is directly related to the names of the territories. In particular, "boz er" means "undeveloped (that is, still new) land", an empty area. And in this sense, the component "boz" forms a number of names on the 
territory of Uzbekistan. For example, the northeastern part of Tashkent (now the northeastern part of Mirzo Ulugbek district of the city) was previously called "Boz-mahalla", since for a long time these lands were not developed by the population and served as grazing lands for pasture (now this name of the mahalla has been restored). It is possible that the river flowing through this territory, according to the name of the area, could be called "Bozsu".

It is assumed that the Bozsu Canal was built at the beginning of the first millennium. In the work "Tarihi Jadiai Tashkent" by the 19th century historian. Muhammad Solih gives a legend that "... During the reign of Tsar Kaikobus and Tsar Salar, by order of Kaikobus in the Bandi Padishah area, a large canal was dug from the Farak (Chirchik) river in terkh tash. In the city, the Bozsu canal flows through the territory of Yunusabad, Shaykhantahur and Uchtepa districts.

\section{CONCLUSION}

In conclusion, we note that the abovementioned works of Russian authors provide information about the history, nature, climate, natural objects of Tashkent, about the organization of city management with administrative institutions, interesting information about the income and expenses of the city, about its improvement and rules relating to this area. Of great importance in the study of the history of the city are data on the number of educational institutions, scientific and educational societies, libraries, museums, book trade, printing and lithography, Orthodox and other churches, synagogues, mosques, medical institutions, charitable institutions and various societies. , government and public institutions. The rich factual material collected by scientists and the indicated brief, but clear and accurate characteristics of the development of various spheres of urban life serve as a valuable source in the reconstruction of the historical toponymy of the city of Tashkent in the late 19th - early 2oth centuries, at the same time, they testify to the great interest shown by sides of the Russian intelligentsia to the study of the history, economy and culture of the Central Asian region.

\section{REFERENCES}

1. Teternikov A.N. Essays on internal trade Kyrgyz steppe. - SPb, 1867.

2. Nazarov F. Posts about some peoples and lands of Central Asia. - M., 1968. - 60 p.

3. Pashino P.I. Turkestanskiy kray v 1866 godu: Putevye zametki s 20 litografiyami. // Turkestanskiy sbornik. - SPb, 1868. T.14. S.98.

4. Kostenko L. Sweden in Russian Tashkent // Turkestanskiy Sbornik. - SPb., 1868. T.28. S.53-97.

5. Pantusov N.N. Materials for prombshlennoy and trade statistics // Materials for statistics Turkestanskogo kraya. Vyp.IV. - SPb, 1876.

6. Maev N.A. Aziatskiy Tashkent // Turkestanskiy Sbornik. - SPb .: Typography V.S.Balasheva, 1876. T.123. S.260-313; Maev N.A. Russkiy Tashkent // Ejemesyachnye prilojeniya pri zhurnale «Niva» na $1894 \mathrm{~g}$. For May, June, July and August. - SPb .: A.F.Marksa Publishing. - S.126-162.

7. Evarnitskiy D.I. Guide to Central Asia from Baku to Tashkent. In archeological and historical relations. - Tashkent, 1893. - p.191193.

8. Divaev A. Promysly i zanyatiya tuzemtsev aziatskogo goroda Tashkenta // «Turkestanskie Vedomosti», 1901, 26 April. - № 33.

9. Shishov A. Sarty. - Tashkent: Electro-steam lithography O.A.Portseva, 1905. - p.39-87.

10. Dobrosmyslov A.I. Tashkent in the past and nastoyashchem. Historical essay. Tashkent: Elektro-parovaya tipo-litografiya O.A.Portseva, 1912. - $520 \mathrm{p}$.

11. Shishkin V.A. About nazvaniyax Tashkentskix mahallya // Bulletin of 
Tashkentskogo Novogorodskogo Ispolkoma. - Tashkent, 1925. - № 4-5.

12. Malitskiy N.G. Tashkentskie maxallya i mauza. - Tashkent, 1927. - P.112-121.

13. Maev N.A. Asian Tashkent // Turkestanskiy Sbornik. - SPb .: Typography V.S.Balasheva, 1876. T.123. - pp.260-321.

14. Maev N.A. Aziatskiy Tashkent // Turkestanskiy Sbornik. - SPb .: Typography V.S.Balasheva, 1876. T.123. - p.297.

15. Maev N.A. Asian Tashkent // Turkestanskiy Sbornik. - SPb .: Typography V.S.Balasheva, 1876. T.123. -C. 131.

16. Shishov A. Sarty. - Tashkent: Electro-steam lithography O.A.Portseva, 1905. -39-54

17. Dobrosmyslov A.I. Tashkent in the past and nastoyashchem. Historical essay. Tashkent: Elektro-parovaya tipo-litografiya O.A.Portseva, 1912. - $520 \mathrm{~s}$

18. Dobrosmyslov A.I. Tashkent in the past and nastoyashchem. Historical essay. Tashkent: Elektro-parovaya tipo-litografiya O.A.Portseva, 1912. - 520

19. Rakhmankulova, Z. (2020). The National Library Of Uzbekistan As A Digital Humanities Center In Uzbekistan. The American Journal of Social Science and Education Innovations, 2(10), 25-33.

20. Rakhmankulova, Z., Choriev, S., Yusupova, D., \& Muminov, O. The Historiography Of The Relations Between Central Asian Khanates And Ottoman Empire In The 19 th and At The Beginning of The 20 th Centuries.

21. Zumrad Rakhmonkulova, Turkish Manuscripts Important Historical Source On The History Of The Relationship Between The Central Asian Khanets And The Ottoman Empire. The American Journal of Social Science and Education Innovations. (ISSN - 2689-100x). Published: October 21, 2020 Pages: 89-96. Doi: https://doi.org/10.37547/tajssei/Volume02ls sue10-14

22. Azizbek Nazarov. History Of The Emergence And Development Of Scientific Societies In The Governor-General Of Turkestan. The American Journal of Social Science and
Education Innovations (ISSN - 2689-100x). Published: October 21, 2020 | Pages: 82-88. Doi:

https://doi.org/10.37547/tajssei/Volumeo2ls sue10-13

23. Daiga Straupeniece, Sherzodjon Choriev. Ethnoculture of The Baltic Nation In Turkestan (1867-1917yy.). The American Journal of Interdisciplinary Innovations and Research (ISSN-2642-7478). Published: October 21, 2020 Pages: 40-52. Doi: https://doi.org/10.37547/tajiir/Volumeo2Issu e10-08

24. Choriev, S. S. (2019). The history of Baltic nation diaspora in Uzbekistan. ISJ Theoretical \& Applied Science, 02 (70), 1925.

25. Nazarov A. Y. (2020). Scientific societies in the Turkestan governorate-general as an instrument of colonial statehood (archival source study). Journal of Critical Reviews ISSN- 2394-5125 Vol 7, Issue 7, P. 1068-1073. http://dx.doi.org/10.31838/jcr.07.07.195 Pp 1068-1073.

26. Nazarov, A. Yo. (2016). Organization of the use of documents Tsentralnogo Gosudarstvennogo archive kinofotofonodokumentov

Republic of Uzbekistan. Document. Archive. History. Sovremennost. Ekaterinburg, 2016, 484-489.

27. Nazarov, A. Y. (2019). The fund of National Archive of Uzbekistan about the scientific institutions in Turkestan. ISJ Theoretical \& Applied Science, 10 (78), 587-589. Soi: http://s-o-i.org/1.1/TAS-10-78-106. Doi: https://dx.doi.org/10.15863/TAS.

28. Choriev SS (2017) CLASSIFICATION OF THE TURKESTAN ASSR DOCUMENTATION IN THE CENTRAL STATE ARCHIVE OF THE REPUBLIC OF UZBEKISTAN. ISJ Theoretical \& Applied Science, 12 (56): 50-54.

29. Choriev, S. S. (2019). The history of Baltic nation diaspora in Uzbekistan. ISJ Theoretical \& Applied Science, 02 (70), 1925.

30. Yusupova Dildora, Khushmatova Sarvinoz. Djadid movement in Khorezm and the 
The American Journal of Social Science and Education Innovations (ISSN - 2689-100x)

Published: October 31, 2020 | Pages: 410-417

Doi: https://doi.org/10.37547/tajssei/Volume02Issue10-66

activities of the Young Khiva residents.

2019, vol. I, issue 13, pp.32-

41..doi.org/10.26739/2181-9599-2019-13-04 